\title{
KPM VERSUS PELNI: PERSAINGAN MEREBUT HEGEMONI JARINGAN PELAYARAN DI NUSANTARA, 1945-1960
}

\author{
Bambang Surowo
}

Arsip Nasional Republik Indonesia
1. Ampera Raya, Cilandak, Jakarta Selatan

Alamat Korespondensi: bambangsurowo@gmail.com

Diterima/ Received: 20 Desember 2015; Disetujui/ Accepted: 28 Januari 2016

\begin{abstract}
This study examines the competition between KPM versus PT Pelni in seizing the network hegemony cruise in the archipelago in 1945 to 1960 using the historical method. KPM is a major shipping company that was also founded by two major companies Rotterdamsche Lloyd $(R L)$ and Stoomvaart Maatschappij Nederland (SMN) headquartered in Amsterdam the Netherlands. KPM serve scheduled regular shipping route for passengers and cargo between islands in the Dutch East Indies then more popular with the term as a post cruise between islands. KPM also play an important role to support and assist the colonial government in the process of penetration and pacification (conquest), especially in areas outside Java. On the other hand, PT PELNI established by the Indonesian government in the framework of the national development of a country that is still young, especially in the field of shipping. PELNI as well as KPM, also serves as centraal vervoersapparaat. Therefore, the government considers KPM c.q PELNI that dominate the cruise between islands in Indonesia are competitors and inhibitors of national development in the field of shipping. Post-transfer of sovereignity and the cancellation of the agreement KMB unilaterally by President Sukarno on May 3, 1956 resulted in the position of Dutch companies including KPM are at stake. This was exacerbated by the outbreak of the conflict between Indonesia and the Netherlands on Dutch New Guinea or West Papua, Indonesia implement the program so that the overall nationalization of the Dutch companies, including KPM.
\end{abstract}

Keywords: KPM; PELNI; hegemony; shipping networks.

\begin{abstract}
Abstrak
Studi ini mengkaji persaingan antara KPM versus PT PELNI dalam merebut hegemoni jaringan pelayaran di Nusantara pada 1945 sampai dengan 1960 menggunakan metode sejarah. KPM adalah perusahaan pelayaran besar yang juga didirikan oleh dua perusahaan besar Rotterdamsche Lloyd (RL) dan Stoomvaart Maatschappij Nederland (SMN) yang berkantor pusat di Amsterdam negeri Belanda. KPM melayani rute pelayaran regular terjadwal bagi penumpang dan muatan kargo antarpulau di Hindia-Belanda yang kemudian lebih populer dengan istilah sebagai pelayaran pos antarpulau. KPM juga berperan penting mendukung dan membantu pemerintah kolonial dalam proses penetrasi dan pasifikasi (penaklukan) daerah-daerah khususnya di luar Jawa. Pada sisi lain, PT PELNI didirikan oleh pemerintah RI dalam rangka pembangunan nasional dari suatu negara yang masih muda, khususnya dalam bidang pelayaran. Oleh karena itu, pemerintah c.q. PELNI menganggap KPM yang mendominasi pelayaran antarpulau di Indonesia merupakan pesaing dan penghambat pembangunan nasional dalam bidang pelayaran. Pasca-penyerahan kedaulatan dan pembatalan kesepakatan KMB secara sepihak oleh Presiden Sukarno pada 3 Mei 1956 mengakibatkan posisi perusahaan-perusahaan Belanda termasuk KPM berada di ujung tanduk. Hal itu diperparah dengan meletusnya konflik antara Indonesia dengan Belanda mengenai Nieuw Guinea atau Papua Barat, sehingga pihak Indonesia melaksanakan program nasionalisasi secara keseluruhan terhadap perusahaan-perusahaan Belanda, termasuk KPM.
\end{abstract}

Kata Kunci: Persaingan, hegemoni, KPM, PELNI, 


\section{PENDAHULUAN}

Sebagai negara bahari, Indonesia tidak hanya memiliki satu "laut utama" atau heart sea, tetapi paling tidak ada tiga laut utama yang membentuk Indonesia sebagai sea system yaitu Laut Jawa, Laut Flores dan Laut Banda. Laut Jawa merupakan kawasan jantung perdagangan laut kepulauan Indonesia, dan telah terintegrasi oleh jaringan pelayaran dan perdagangan sebelum datangnya bangsa Barat. Sementara itu Houben menyatakan bahwa laut Jawa bukan hanya merupakan laut utama bagi Indonesia, tetapi juga merupakan laut inti bagi kawasan Asia Tenggara (Houben, Maier, dan Molen, 1992: vii). Sejarawan yang secara lebih khusus menulis mengenai sejarah perdagangan maritim di Indonesia adalah Meilink Roelofzs. Dalam bukunya, ia melukiskan bahwa sebelum kedatangan para pedagang Portugis dan Belanda telah berlangsung perdagangan antarpulau di wilayah Indonesia. Barang-barang dagangan utama yang diperdagangkan dalam skala yang besar adalah beras dan lada, dan dengan menggunakan kapal-kapal pribumi yang cukup besar (Meilink-Roelofsz, 1962).

Dunia bahari dalam sejarah Indonesia juga tidak bisa dilepaskan kaitannnya dari kondisi fisik atau geografis wilayah Indonesia. Menurut Ensiklopedi Nasional Indonesia dapat diketahui bahwa wilayah Indonesia terletak antara dua benua yaitu Asia dan Australia, dan antara dua samudra yaitu samudra Hindia (Indonesia) dan samudra Pasifik, terdiri dari lebih 13.000 pulau, mulai dari pulau We di ujung utara/ barat sampai pulau Irian di ujung timur, dengan perbandingan wilayah laut (78\%) dan darat (22\%) (Ensiklopedia Nasional Indonesia, 1989: 74-75). Pulaupulau dalam wilayah Indonesia itu terbentang menyebar sejauh $6.400 \mathrm{~km}$ dari timur ke barat dan sejauh $2.500 \mathrm{~km}$ dari utara ke selatan, sedangkan garis terluar yang mengelilingi wilayah itu sekitar $81.000 \mathrm{~km}$ (Wertheim, 1969: 16-37; Walcott, 1914: 1; KPM, 1938: 37; dan Ali, 1966: 27). Sumber yang lain menyebutkan bahwa Indonesia memiliki wilayah seluas sekitar $587.000 \mathrm{~km} \bigotimes$ sementara jarak dari ujung paling timur ke ujung paling barat sebagaimana digambarkan oleh Multatuli adalah lebih panjang daripada jarak antara London sampai Siberia (Drake, 1989: 16).

Sehubungan dengan hal itu, adalah kurang bijaksana melihat sejarah Indonesia dari sisi daratan saja, sehingga pengetahuan dan pandangan tentang masa lampau yang merupakan dasar untuk mengenal dan mengerti masa kini menjadi berat sebelah. Penulisan sejarah yang berpretensi atau beraspirasi Nasional dalam arti yang sebenarnya dianggap tidak lengkap apabila yang diutamakan hanya unsur darat saja dari yang seharusnya sejarah tanah air. Hal ini menjadi lebih penting lagi sesudah Wawasan Nusantara diterima dan diakui sebagai pandangan resmi yang dianut oleh pemerintah dan bangsa Indonesia. Wawasan ini tidak lagi melihat Negara Republik Indonesia sebagai suatu kesatuan berdasarkan prinsip pulau-demi-pulau, melainkan suatu negara kepulauan (archipelagic state) yang mempunyai kebulatan teritorial termasuk laut dan selat yang berada di dalam garis perbatasan yang telah ditentukan. Azas 'Negara Kepulauan' resmi diumumkan lewat Deklarasi Juanda pada 13 Desember 1957 dan diperjuangkan pada tingkat internasional selama 25 tahun.

Dalam perjalanan sejarahnya, bangsa Indonesia pernah mengalami kejayaan dalam bidang maritim. Hal itu dapat diketahui dari adaya masa kejayaan kerajaan-kerajaan maritim yang pernah tampil dalam panggung sejarah Indonesia. Di antara kerajaan-kerajaan itu juga saling berhubungan melalui transaksi perdagangan dan pelayaran perahu. ${ }^{1}$ Salah satu kerajaan maritim yang besar dan terkenal di Nusantara pada waktu itu adalah kerajaan Sriwijaya yang berlangsung dari abad ke-7 sampai 14. Dalam dunia perdagangan dan pelayaran, Sriwijaya berhasil menguasai hampir semua wilayah perairan di Nusantara antara lain Laut Jawa, Laut Banda, dan sebagian laut di wilayah Indonesia Timur. Di Makassar terdapat kerajaan GowaTallo. Sementara itu Jawa terdapat kerajaan Majapahit (1293-1525) yang agraris dan juga maritim. Setelah kemerosotan Majapahit pada 
abad ke-16, di Jawa muncul kerajaan maritim baru, yaitu Demak. Sementara di luar Jawa, terutama di Sulawesi pelaut Makassar dan Bugis pada abad ke-17 telah melakukan pelayaran hampir ke seluruh parairan Nusantara (Indonesia). Dengan demikian dapat dikatakan, sampai abad ke-17 wilayah Nusantara telah terintegrasi dalam suatu jaringan pelayaran dan perdagangan dari berbagai suku bangsa yang ada di kawasan itu.

Kemunduran kerajaan-kerajaan maritim di Nusantara di samping disebabkan oleh persaingan atau konflik interen dari kerajaankerajaan tersebut, juga disebabkan oleh kedatangan bangsa Barat yang tujuan utamanya adalah untuk berburu komoditas khususnya rempah-rempah, tetapi secara berangsur-angsur akhirnya menjajah Indonesia. Verenigde Oost Indische Compagnie (VOC) berhasil memaksakan monopoli perdagangan, sedangkan setelah VOC gulung tikar pemerintah Belanda menggantikannya dan menjajah Nusantara dengan pemerintahan Hindia-Belandanya.

Sebagai contoh yang menarik mengenai kasus kemerosotan kerajaan maritim di Nusantara adalah pelabuhan Tuban. Pada zaman awal kejayaan kerajaan Majapahit pada 1350-an Tuban merupakan kota dan pelabuhan terbesar di Nusantara. Di pelabuhan itulah berkumpul para pedagang kaya, pemilik modal layaknya kaum borjuis di Eropa abad ke-19, yang dengan kekayaan dan para pengawalnya yang besar mempunyai pengaruh dalam bidang politik dalam kerajaan (Bebler, 1963: 25).

Merebaknya kekuasaan VOC di Nusantara ditandai dengan keberhasilan J.P. Coen menyerang dan merebut Sunda Kelapa (Jakarta sekarang) pada 30 Mei 1619. Bahkan kota pelabuhan yang makmur itu dibakar habis oleh pasukan VOC di bawah J.P. Coen (Heuken, ?: 136, 157, 158; Mulyana, 1980: 98). Sebagai Gubernur Jendral VOC dikemudian hari, ia menjadikan Sunda Kelapa menjadi pos atau benteng yang aman di Nusantara, sebagai pusat administrasi, perdagangan dan politik pemerintahan VOC, dengan nama baru Batavia.
Dari pusat pemerintahannya di Batavia inilah, VOC terus-menerus merencanakan sistem perdagangan monopoli di seluruh wilayah Nusantara, khususnya di daerah-daerah atau kota-kota pelabuhan. Taktik licik yang ditempuh adalah dengan menjalankan politik adu domba (Devide et Impera) dan intervensi politik dalam urusan interen di berbagai kerajaan pribumi. Ricklefs menyebutkan bahwa dalam setiap peranan kompeni Belanda dalam membantu dan menjaga kedudukan pewaris tahta kerajaankerajaan pribumi, berakibat semakin mendorong timbulnya konflik-konflik interen dalam istana, kekacauan atau bahkan pemberontakan. Untuk yang disebut terakhir inilah kompeni Belanda biasa mengambil sikap memihak kepada yang diharapkan akan memberi konsesi politik dan ekonomi lebih besar (Rickelfs, 1974: 51).

Pemerintahan Hindia Belanda yang menggantikan VOC berusaha keras untuk menguasai seluruh daerah-daerah di Nusantara. Selama abad ke-19 dan bahkan sampai awal abad ke-20 Belanda terus melakukan terus serentetan penaklukan dan penghancuran terhadap berbagai perlawanan rakyat di berbagai daerah di Nusantara, khususnya di luar Jawa. Sebagai hasilnya Belanda akhirnya berhasil mewujudkan cita-citanya, yaitu apa yang disebut $P a x$ Neerlandica, atau sebuah imperium Belanda Raya. Artinya, bahwa selama masa itu aktivitas kemaritiman penduduk Nusantara berada di bawah pengawasan dan kekuasaan kolonialisme Belanda. Dalam praktik baik pelayaran domestik maupun pelayaran internasional di kawasan Nusantara dikendalikan oleh perusahaan Belanda sendiri, khususnya N.V. Koninklijk Paketvaart Maatschappij (KPM) yang secara tidak langsung mendapatkan monopoli atas pelayaran di Hindia Belanda. Kemudian KPM juga dimanfaatkan oleh pemerintah kolonial Belanda dalam membangun infrastruktur jalur pelayaran yang memungkinkannya mengontrol seluruh wilayah Hindia Belanda secara politis, dalam rangka mencapai integrasi negara kolonial di bawah bendera Pax Neerlandica (à Campo, 1992: 21-22). 
Meskipun berada di bawah dominasi Belanda tidak berarti bahwa aktivitas kemaritiman seluruh suku bangsa di wilayah Nusantara menjadi terhenti. Hanya saja aktivitas mereka, khususnya suku-suku di berbagai pulau di luar Jawa, terbatas pada pelayaran dan perdagangan antarpulau. Juga terdapat sejumlah pelaut dan pedagang pribumi yang lebih memilih atau mengubah profesi mereka menjadi perompak di laut, dan ada yang sebagian lagi menghindar atau menyingkir ke pedalaman untuk menjadi petani.

Kemerosotan pelayaran penduduk pribumi mencapai puncaknya selama masa pendudukan Jepang. Pada masa itu jaringan pelayaran antarpulau diambil alih dan dikuasai oleh militer Jepang dalam rangka Perang Asia Timur Raya, sementara kapal-kapal KPM, untuk sebagian disita Jepang dan sebagian lagi keluar dari perairan Indonesia. Bahkan kapal-kapal milik orang-orang Cina dari Singapura yang selama periode kolonial menjadi pesaing KPM juga tidak banyak lagi bermunculan di perairan Indonesia. Dengan demikian, bisa dikatakan bahwa periode pendudukan Jepang ini merupakan masa yang sangat gelap dalam sejarah pelayaran dan perdagangan antarpulau di Indonesia.

Sesudah Jepang menyerah dan Indonesia memasuki masa Revolusi, Belanda berusaha membangun kekuasaannya di Hindia-Belanda baik dalam bidang keamanan, politik, dan ekonomi. Pada periode ini Belanda berusaha keras untuk mengembalikan dominasi pelayarannya di Indonesia, khususnya dengan membangkitkan kembali eksistensi KPM (Panitia Penjusun Naskah Buku '20 Tahun Indonesia Merdeka', 1966: 640).

Dengan dalih untuk memajukan pelayaran pantai, pihak Belanda yang diwakili oleh Departemen Urusan Ekonomi (Departement van Economische Zaken) dan KPM pada 14 Maret 1947 mendirikan Stichting Gemeenschappelijk Schappenbezit (SGS). Dalam pelaksanaannya SGS menyewa kapal-kapal dari KPM dari Pemerintah Hindia Belanda, kemudian disewakan kepada perusahaan-perusahaan pelayaran nasional daerah. Untuk maksud tersebut didirikanlah Dochter Maatschappeijen dalam bentuk perusahaan nasional di daerahdaerah, tetapi SGS memiliki bagian saham yang terbesar. Dengan demikian dapat dikatakan bahwa pendirian SGS semata-mata bertujuan untuk memperkuat kedudukan KPM, karena melalui badan-badan SGS, KPM tetap menduduki posisi monopoli dalam pelayaran di perairan Indonesia. Pada 1949 ketika Belanda telah mengakui dan menyerahkan kedaulatan Indonesia, kedudukan KPM yang sangat kuat ini tetap diusahakan oleh pihak Belanda untuk tetap dipertahankan.

Pada pihak lain, yaitu Republik Indonesia yang telah merdeka, juga ingin menguasai dan mengembangkan pelayaran dan perdagangan nasional. Sehubungan dengan hal itu, berdasarkan Surat Keputusan Menteri Perhubungan, Pekerjaan Umum dan Tenaga Kerja No.3260/Ment. tanggal 5 September 1950 didirikan Yayasan Penguasaan Pusat Kapal-kapal (Pepuska). Sementara SGS yang didirikan oleh Belanda dibubarkan dengan ketentuan, dan fungsi serta harta kekayaannya diambil alih oleh Yayasan Pepuska. Tujuan dari pendirian Pepuska adalah untuk mengembangkan pelayaran nasional dengan tugas kerja yang meliputi pembinaan pelayaran pantai dan pelayaran samudera nasional. Namun demikian, dalam praktik sulit untuk dilaksanakan. Dalam pelaksanaannya, ternyata usaha Yayasan Pepuska tidak seperti yang diharapkan. Oleh karena itu, diperlukan kiat baru dengan melibatkan peranan negara dalam bidang pelayaran, yaitu harus dibentuk suatu perusahaan pelayaran milik negara, yang akan merupakan suatu centraal vervoersapparaat yang nantinya diusahakan secara berangsur-angsur mengambil alih usaha pelayaran KPM.

Untuk merealisasikan tujuan tersebut, maka berdasarkan Surat Keputusan Menteri Perhubungan No. M.2/1/tanggal 28 Februari 1952 dan No. A.2/1/1 tanggal 19 April 1952, didirikan PT Pelayaran Nasional Indonesia (PT PELNI), sedangkan Yayasan Pepuska dilikuidasi dengan ketentuan, bahwa uang dan harta 
kekayaan diinvestasikan kepada PT PELNI. Pada akhir 1957 sebagai akibat dari konflik Irian Barat, yaitu perjuangan bangsa Indonesia merebut kembali wilayah itu dalam kesatuan Republik Indonesia, maka KPM terpaksa harus meninggalkan Indonesia. Setelah diadakan penarikan kapal-kapal KPM dari perairan Indonesia, maka keluarlah Peraturan Pemerintah No. 47/1957, dan Surat Keputusan Menteri Pelayaran tanggal 10 Maret 1958 No. Plj. $1 / 1 / 14$, dengan tujuan untuk mengusahakan dan memenuhi kebutuhan jasa angkutan laut dalam negeri, dan menetapkan jaringan angkutan laut yang baru menggantikan KPM. Dengan demikian, sejak saat itu PT PELNI mulai berkiprah untuk mengembangkan pelayaran dalam negeri dengan berbagai fasilitasnya.

Berdasar pada uraian singkat latar belakang kesejarahan pelayaran di Indonesia sampai pada berdirinya PT PELNI, maka permasalahan yang akan dibahas adalah bagaimanakah sejarah perkembangan KPM, bagaimanakah latar belakang pendirian PELNI dan bagaimanakah usaha-usaha pemerintah RI dan PELNI untuk menggantikan peranan KPM.

Metode penelitian yang dipergunakan dalam penelitian ini adalah metode sejarah, yang pada garis besarnya terdiri dari empat langkah secara berurutan, yaitu sebagai berikut.

Pertama, heuristik, yaitu kegiatan mencari dan mengumpulkan sumber-sumber sejarah. Sumber-sumber itu terdiri dari sumber primer yang berupa dokumen atau arsip yang bisa ditemukan di lembaga Arsip Nasional Republik Indonesia dan sumber-sumber sekunder yang berupa buku-buku penunjang, majalah, koran, terbitan berkala, dan sebagainya. Khusus mengenai sumber arsip yang terutama adalah arsip Sekretariat Negara dan khasanah arsip dari Departemen Perhubungan dan juga dari PT PELNI. Sementara sumber sekunder yang berguna sebagai sumber pendukung atau pelengkap bisa diperoleh dari berbagai perpustakaan di Jakarta dan dari internet.

Kedua, kritik sumber, yaitu kegiatan yang bertujuan untuk menyelidiki dan menguji apakah sumber-sumber sejarah yang ditemukan itu bisa dipercaya (kredibel) baik dalam bentuk maupun isinya. Dengan demikian tahap ini merupakan kegiatan untuk mencari informasiinformasi yang bisa dipercaya dari sumbersumber sejarah, yang dalam Ilmu Sejarah disebut dengan istilah fakta sejarah.

Ketiga, interpretasi, adalah kegitatan menetapkan makna dan saling hubungan antara fakta-fakta sejarah yang telah diperoleh melalui kritik sumber. Dalam hal ini dari banyak fakta sejarah yang telah diperoleh harus dirangkaikan atau dihubung-hubungkan satu sama lain sehingga menjadi satu kesatuan yang harmonis, menurut rangkaian yang kronologis dan hubungan sebab akibat.

Keempat, Historiografi atau rekonstruksi sejarah, yaitu kegiatan melakukan sintesis sejarah, atau menyajikan hasil penelitian dalam bentuk kisah sejarah.

\section{DINAMIKA KPM SAMPAI 1952}

KPM adalah perusahaan pelayaran negara (kerajaan) Belanda yang kantor pusatnya berlokasi di Batavia (Jakarta sekarang), tetapi status hukumnya berkedudukan di Amsterdam negeri Belanda. Pada masa kolonial KPM memainkan peranan kunci dalam pasifikasi wilayah Nusantara sehingga berada sepenuhnya di bawah kekuasaan Belanda. Hal ini bukan berarti bahwa di Indonesia atau Nusantara tidak pernah terdapat aktivitas pelayaran dan perdagangan yang membentuk jaringan pelayaran Nusantara. Bukti-bukti sejarah menunjukkan bahwa di Nusantara pernah berjaya kerajaan-kerajaan maritim yang telah mengembangkan jaringan pelayaran perdagangan sampai jauh keluar Nusantara. ${ }^{1}$ Cara khas yang dilakukan oleh kolonialisme Belanda untuk menguasai dunia maritim di Nusantara adalah tetap mempertahankan monopoli warisan zaman VOC dengan modus operandi yang baru.

Terdapat faktor lain yang ikut mendorong usaha Belanda untuk mempercepat penguasaan jaringan pelayaran dan perdagangan di Nusantara adalah perkembangan teknologi 
perkapalan dan pelayaran moderen, yang juga merupakan salah satu aspek dari proses perkembangan teknologi baru yang terjadi di dunia Barat. Hal itu berkaitan erat dengan ditemukannya mesin uap pada abad ke-18 oleh James Watt, yang selanjutnya juga ikut mendorong perkembangan teknologi perkapalan, yaitu dengan dikembangkannya kapal bermesin uap (steamboat).

Salah satu perusahaan Belanda yang telah beroperasi di Hindia-Belanda dan juga telah menggunakan kapal uap sebelum berdirinya KPM adalah Nederlandds Indische Stoomboot Maatschappij (NISM) yang didirikan oleh William Mackinnon pada 1864 ("Koninklijke Paketvaart Maatschappij 1888-1967”). NISM sesungguhnya adalah cabang dari perusahaan pelayaran yang ada di Belanda yaitu NSM (Chia Joshua, Yeong Jia, dan Loh Pei Ying, 2007). NISM merupakan cabang dari British India Steam Navigation Company, yang dimiliki oleh beberapa orang Inggris, yang salah satunya adalah William Mackinnon. Namun demikian, pada 1865 NISM memperoleh monopoli pelayaran antarpulau di Hindia-Belanda oleh pemerintah Belanda.

Sementara itu, perusahaan swasta Belanda yang berkedudukan di negeri Belanda (Amsterdam) adalah Stoomvaart Maatschappij Nederland (SMN). Perusahaan ini terutama berfokus pada rute negeri Belanda dan Jawa yang kemudian lebih populer dengan istilah pelayaran pos. Perusahaan ini juga melayani pelayaran regular terjadwal bagi penumpang dan muatan kargo antarpulau di Hindia Belanda. Di samping SMN juga terdapat perusahaan Belanda yang lain, yaitu Rotterdamsche Lloyd (RL). Perusahaan ini mempunyai trayek yang hampir sama dengan SMN. Kedua perusahaan itu (SMN dan $\mathrm{RL}$ ), merasa sangat tersaingi oleh perusahaanperusahaan Inggris dan Jerman yang berpangkalan di Singapura, yang menguasai dan melayani jalur pelayaran antara Sumatra Utara dan Singapura, khususnya dalam rangka melayani perdagangan tembakau yang sangat menguntungkan. Persaingan tersebut terutama terhadap NISM. Karena, meskipun berbendera Belanda, perusahaan tersebut sesungguhnya milik orangorang Inggris. Lebih dari itu, NISM juga memperoleh kontrak dan subsidi dari pemerintah Belanda untuk melayani pelayaran pos dan penumpang antarpulau. Pimpinan SMN dan RL juga mencurigai bahwa NISM melakukan pelanggaran dengan melalui jalur-jalur nonkontrak dalam pelayaran antarpulau Jawa dan Luar Jawa.

Ketika kontrak NISM hampir berakhir, yaitu pada 1890, manajemen SMN dan RL berusaha untuk menyebarkan wacana untuk membangkitkan rasa patriotisme Belanda dalam dunia pelayaran. Sehubungan dengan hal itu, ketika pada 1886 pemerintah Belanda menawarkan tender untuk kontrak baru, SMN dan RL tidak menyia-nyiakan kesempatan itu dan segera mengajukan usulan dan penawaran tender tersebut. Hasilnya, pada 1887 kedua perusahaan itu memenangkan tender, dan menandatangani kontrak dengan pemerintah. Selanjutnya pada Januari 1888 kedua perusahaan pelayaran tersebut mendirikan perusahaan pelayaran baru yang diberi nama KPM (Staatsblad 1888, No. 48). Akhirnya KPM resmi berdiri pada 4 September 1888. Dalam akte pendiriannnya disebutkan tujuan perusahaan yaitu menyelenggarakan pelayaran wajib sesuai perjanjian dengan pemerintah, melayani angkutan barang dan penumpang dengan kapalkapal api atau layar milik sendiri atau yang disewa.

Sejak saat itu, jalur pelayaran antarpulau di Hindia Belanda yang semula dikuasai oleh NISM digantikan oleh KPM. KPM juga berfungsi sebagai penopang stabilitas jalur pelayaran di Hindia Belanda. Bahkan pada zaman kolonial Belanda, KPM juga memainkan peranan kunci dalam pasifikasi wilayah Nusantara khususnya di luar Jawa, sehingga menjadi berada di bawah kekuasaan Belanda (Kerkhof, 2005: 134).

Perlu ditekankan di sini, bahwa tujuan pendirian KPM bukan semata-mata untuk kepentingan ekonomi atau perdagangan, tetapi juga sebagai centraal vervoersapparaat (badan angkutan pusat). Pada 1 Januari 1931, disepakati perjanjian antara pemerintah Hindia Belanda 
dengan KPM yang terkenal dengan nama Groot Archipel Contract (GAC).

Melalui GAC tersebut, KPM sebagai Centraal Vervoers Apparaat diberi hak monopoli atas pelayaran antarpulau (interinsuler) di Hindia Belanda. Termasuk di dalamnya adalah hak monopoli dalam pengangkutan militer, pengangkutan bahan-bahan pokok, dan perbekalan. Di samping itu, KPM juga harus menjamin pelayaran yang tetap dan teratur, sehingga hubungan antara daerah-daerah minus dan terpencil dengan pusat tetap terpelihara.

Untuk lebih memperkuat dominasi dan monopoli KPM, pada 1936 pemerintah Hindia Belanda mengeluarkan undang-undang pelayaran, Indische Scheepvaartwet. Undang-undang tersebut menetapkan bahwa pelayaran pantai hanya diperuntukkan bagi kapal-kapal berbendera Belanda dan pribumi. Penerbitan dan implementasi undang-undang itu sesungguhnya merupakan bentuk proteksi pemerintah Belanda terhadap para saingan KPM, yaitu perusahaanperusahaan pelayaran Inggris dan Cina yang bermarkas di Singapura. Meskipun menikmati berbagai keistimewaan, KPM tetap mengalami kesulitan dalam mempertahankan hak monopoli. Sebagai contoh, KPM ternyata harus menghadapi pesaing kapal-kapal atau perahuperahu kecil, yang dikenal dengan sebutan "armada semut" yang banyak beroperasi di daerah pantai Sumatra Timur, pantai barat Kalimantan, serta daerah produksi kopra di Sulawesi Utara dan Maluku Utara. Untuk memenangkan persaingan tersebut, pada 1935 KPM mendirikan apa yang disebut Celebes Kustvaart Maatschappij (CEKUMIJ). CEKUMIJ merekrut para pemilik kapal-kapal armada semut atau kapal-kapal kecil melalui pemilikan saham, agar mengikuti ketentuan atau keinginan KPM dan bukan menjadi pesaingnya.

Setelah pemerintahan kolonial Belanda berakhir, Indonesia mengalami babakan sejarah baru, yaitu berkuasanya pemerintahan pendudukan Jepang. Di bidang politik dan pemerintahan, Jepang menjalankan tindakan politik secara radikal. Sebagai contoh, militer Jepang membubarkan semua organisasi rakyat Indone- sia, kecuali organisasi atau perkumpulan yang didukung dan didirikan oleh Jepang dengan tujuan agar dapat dipergunakan atau dimanfaatkan guna membantu usaha-usaha perang.

Sebagai akibat sikap dan tindakan yang radikal itu maka terjadilah perubahan-perubahan politik, pemerintahan, dan ekonomi yang cukup fundamental. Hal itu terjadi sebagai akibat hancurnya institusi-institusi kolonial Belanda yang sudah mapan, yang kemudian digantikan dengan institusi-institusi bentukan Jepang yang cenderung militeristik. Di samping itu, pemerintah pendudukan Jepang berusaha dengan segala cara, baik dengan cara damai maupun kekerasan, dalam mengeksploitasi potensi sosial, politik, dan ekonomi, dengan tujuan utama untuk mendukung militer Jepang dalam rangka Perang Asia Timur Raya.

Sebagai akibat tindakan Jepang itu, maka aktivitas industri, pelayaran, dan perdagangan luar negeri mengalami kelumpuhan. Demikian juga aktivitas pelayaran di Hindia Belanda, khususnya yang dimiliki oleh perusahaan asing Eropa/ Belanda juga mengalami stagnasi. Hal itu disebabkan oleh tindakan tentara pendudukan Jepang yang merampas atau menyita segala sarana pelayaran yang ada untuk mendukung perang melawan Sekutu.

Tanpa terkecuali tindakan Jepang itu juga menimpa perusahaan-perusahaan pelayaran yang ada di Hindia Belanda termasuk KPM. Pada waktu itu, Jepang menyita semua perusahaan pelayaran dan perdagangan yang ada di Hindia Belanda. Sebagai akibatnya, semua kegiatan ekonomi komersial, termasuk perdagangan dan pelayaran baik interinsuler, maupun internasional terhenti, kecuali yang dilakukan oleh Jepang sendiri.

Berakhirnya pemerintahan pendudukan Jepang di Indonesia ditandai dengan Proklamasi Kemerdekaan Republik Indonesia pada 17 Agustus 1945. Meskipun Indonesia telah diproklamasikan, bukan berati bahwa negara yang masih muda itu bebas dari ancaman penjajahan. Bangsa Indonesia yang baru merdeka harus menghadapi Sekutu (Inggris), yang ternyata 
diboncengi oleh Belanda yang berusaha merebut tanah jajahannya kembali.

Kedatangan Sekutu di berbagai daerah pada awalnya diterima dengan tangan terbuka. ${ }^{2}$ Akan tetapi, setelah diketahui bahwa pasukan ini juga membawa orang-orang Netherlands Indie Civil Administration (NICA) yang dengan tujuan ingin menegakkan kembali kekuasaan pemerin-tah Hindia Belanda, maka sikap Pemerintah Republik berubah. Di berbagai daerah, hal itu menimbulkan konflik-konflik bersenjata, seperti yang terjadi di Semarang dan Surabaya.

Konflik antara para pejuang Indonesia melawan Belanda itu berlangsung sampai 1949. Oleh karena situasi yang berkecamuk, Indonesia belum dapat melepaskan diri dari cengkeraman ekonomi kolonial yang sudah berabad-abad menguasai Indonesia. Namun demikian, hal ini dapat dimengerti, karena bangsa Indonesia pada masa itu masih harus menghadapi Belanda yang ingin kembali menjajah Indonesia.

Aksi-aksi militer Belanda yang menurut versi mereka bertujuan untuk menegakkan dan mengembalikan kembali kekuasaan di tanah jajahan Indonesia, terjadi di berbagai kota, khususnya di Jawa. Hal itu dikenal dengan istilah Aksi Polisionil (Clash) I pada 1947 dan II pada 1948. Bagi pihak pejuang hal itu merupakan aksi merebut kekuasaan negara Indonesia yang telah merdeka. Pada Aksi Polisionil I, Belanda berhasil menduduki kota-kota besar di Pulau Jawa, kecuali Yogyakarta, yang baru berhasil diduduki dalam Aksi Polisionil II (Nasution, 1977: 376).

Selama masa pendudukan itu, Belanda berusaha untuk menghidupkan kembali aktivitas berbagai pelabuhan yang ditinggalkan oleh Jepang. Namun demikian, oleh karena banyak terjadi kerusakan selama perang dan pendudukan Jepang, Belanda harus terlebih dahulu melakukan perbaikan-perbaikan sarana dan prasarana (infrastruktur) pelabuhan. Selanjutnya kepada para pengusaha Belanda yang bergerak dalam bidang pelayaran dan perdagangan di pelabuhan-pelabuhan itu diberi kesempatan untuk memperoleh kembali aset- aset mereka yang sebelumnya diduduki oleh Jepang.

Usaha-usaha rekolonisasi dari pelayaran Belanda di perairan Indonesia juga dilakukan oleh KPM. KPM membangun kembali armada dan agen-agennya di Indonesia. Namun demikian, sehubungan dengan bergulirnya revolusi, usaha pembangunan armada banyak menemui hambatan. Oleh karena itu, baru pada 1950 KPM menambah kapal-kapal baru berjumlah 110 unit dengan tonase 176.601 Bruto Register Tonnage (BRT). Sebelumnya, KPM hanya memiliki armada sebanyak 146 unit.

Bagi pemerintah Belanda, mempertahankan keberadaan KPM di Indonesia adalah hal yang prinsip. Hal itu karena KPM pernah memainkan kunci dalam usaha pasifikasi daerahdaerah Nusantara khususnya di luar Jawa. Namun pada masa itu posisi KPM sulit dipertahankan. Hak monopoli atas pelayaran interinsuler yang didasarkan pada GAC pada 1931, setelah 1 Januari 1946 tidak diperpanjang lagi. Meskipun demikian KPM tetap memperoleh subsidi, mengangkut barang-barang dan penumpang milik gubernemen (Kerkhof, 2005: 129; á Campo, 1998: 2).

Untuk mempertahankan eksistensinya dan agar memperoleh simpati, pemerintah Belanda mencoba untuk memberi kesempatan dan peran yang lebih penting kepada mereka dalam aktivitas pelayaran di Indonesia. Pada 14 Maret 1947, pihak Belanda yang diwakili oleh Departement van Economische Zaken (Departemen Urusan Ekonomi) dan NV KPM mendirikan Stichting Gemeenschappelijk Scheppenbezit (SGS), yang arti harafiahnya yayasan kepemilikan kapal bersama. Tugas utama SGS adalah mendirikan perusahaan pelayaran pantai/ lokal dengan perbandingan pemilikan saham perusahaan sebanyak $45 \%$ atas nama SGS dan $55 \%$ untuk warga Indonesia. Di samping itu, SGS juga membantu pengusaha atau perusahaan pelayaran pribumi Indonesia yang diberi tugas untuk mengangkut barang-barang atau komoditas dari daerah-daerah pantai di sekitar pelabuhan-pelabuhan utama dimana kapal-kapal 
KPM berlabuh. Tugas kapal-kapal kecil tersebut disebut dengan istilah Feederdiensten.

Melalui pendirian SGS mulai berlaku pengaturan tugas. Kapal-kapal KPM bertugas mengangkut barang-barang dari dan ke pelabuhan utama atau induk, sebaliknya kapalkapal SGS mengangkut barang-barang dari daerah-daerah di sekitar pelabuhan utama. Di samping itu, di berbagai daerah juga didirikan apa yang disebut Dochter Maatschappij, yaitu perusahaan-perusahaan pelayaran swasta sebagai feederliners, yang lingkup pelayarannya sama dengan Feederdiensten. SGS memilik bagian yang cukup besar dalam sahamnya. Namun demikian usaha-usaha untuk membangkitkan pelayaran pantai penduduk pribumi kurang sukses. Hal itu karena, jumlah kapal dan personel yang berkualitas di wilayah Republik sangat kurang (Sulistiyono, 2003: 18).

\section{PERSAINGAN ANTARA PT PELNI DENGAN KPM}

Sebagai negara yang memiliki laut luas, pemerintah Indonesia pada waktu itu juga bercita-cita membangun pelayaran nasional. Meskipun demikian, cita-cita itu harus menghadapi kenyataan akan keberadaan KPM yang masih boleh beroperasi dan mendominasi jaringan pelayaran antarpulau di Indonesia. Sebaliknya bagi Indonesia adalah hal yang ironis jika menerima monopoli asing dalam bidang pelayaran antarpulau yang menjadi sarana untuk membangun persatuan dan integrasi nasional. Usaha pertama yang dilakukan oleh pemerintah pada waktu itu adalah mengajukan tawaran kepada direksi KPM untuk bekerja sama dalam bentuk joint venture kepemilikan saham KPM.

Tawaran usulan kepemilikan saham oleh Indonesia itu, baik dalam kepemilikan saham yang menempatkan Indonesia lebih dominan. Ketentuan pembayaran dan pengambilalihan seluruh armada KPM secara berangsur-angsur ditolak dengan tegas oleh direksi KPM. Penolakan tawaran Indonesia oleh direksi KPM itu tentu tidak menghentikan cita-cita RI untuk tetap berusaha membangun dan mengembangkan perusahan pelayaran nasional yang harus menjadi tuan di negeri sendiri. Pada Oktober 1950, Perdana Menteri Natsir menyatakan bahwa Indonesia tidak lagi menganggap dirinya terikat pada GAC 1931.

Meskipun memperoleh bantuan dari KPM dalam rangka menumpas pemberontakan di Maluku dan Sulawesi Selatan, cita-cita pemerintah Indonesia untuk mengembangkan pelayaran nasional tetap terus diperjuangkan. Langkah pertama untuk merealisasi cita-cita itu adalah pendirian Yayasan Penguasaan Pusat Kapal-kapal (Pepuska) berdasar Surat Keputusan Menteri Perhubungan, Pekerjaan Umum dan Tenaga Kerja No.3260/Ment. tanggal 5 September 1950.

Sementara SGS, yang juga dianggap sebagai penerus rezim kolonial dalam bidang pelayaran, dinasionalisasi dan selanjutnya dibubarkan. Dalam pengambilalihan itu tidak berarti bahwa Pepuska juga mengambil alih kapal-kapal KPM yang dioperasionalkan oleh SGS, tetapi hanya menyewanya saja.

Meskipun dapat dikatakan berhasil meningkatkan usaha khususnya dalam pengadaan kapal, tetapi Pepuska dianggap kurang profesional. Kapal-kapal yang dibeli ternyata berkualitas rendah, sehingga sering mengalami kerusakan dan naik dock. Oleh karena itu, pada April 1952 yayasan itu dibubarkan. Namun demikian, dari pihak Indonesia muncul gagasan untuk membentuk suatu perusahaan pelayaran milik negara, yang akan merupakan suatu centraal vervoersapparaat seperti zaman Belanda. Gagasan ini merupakan suatu konsepsi yang sangat tepat dalam rangka pembinaan pelayaran nasional, salah satu sendi pokok dalam politik strategi perhubungan laut, dan langkah positif dari pemerintah yang tepat.

Untuk membuktikan gagasan dan komitmen pemerintah Indonesia itu, melalui suatu perundingan dengan DPR pada 1951, Menteri Perhubungan menandatangani Surat Keputusan No. M.2/12 tanggal 12 Februari 1952 dan No. A.2/1/1-19 April 1952 mengenai persetujuan pendirian PT Pelayaran Nasional Indonesia (PELNI). Selanjutnya pendirian itu juga berdasar pada Surat Keputusan Menteri 
Perhubungan (Ir. R. Djuanda) No. M.2/1/tanggal 28 Februari 1952 dan No. A.2/1/1 tanggal 19 April 1952. Akhirnya berdasar pada akte Notaris No. 92 tahun 1952, tanggal 28 April 1952 secara resmi PT PELNI berdiri.

Pendirian PT PELNI pada 1952 dapat dianggap sebagai awal keruntuhan KPM di Indonesia. Namun demikian, mengingat keterbatasan ahli ekonomi komersial dan kemaritiman, keadaan keuangan negara yang tidak menentu, dan keterbatasan kapal yang dimiliki Indonesia, pendirian PT PELNI dengan visi nasionalnya bisa dianggap sangat ambisius. PT PELNI menjadi lembaran baru dalam sejarah pelayaran nasional Indonesia.

Sejak itu, terdapat dua perusahaan pelayaran interinsuler di Indonesia, yang masingmasing merupakan simbol dari dua bangsa. KPM yang didukung dan dilindungi pemerintah Belanda serta PT PELNI yang didukung oleh pemerintah Indonesia. Seperti halnya KPM pada zaman kolonial Belanda, PT PELNI juga mempunyai tugas sebagai centraal vervoersapparaat dan menikmati posisi istimewa dengan tugas mengangkut barang dan penumpang.

Untuk bersaing melawan KPM yang sudah mulai bangkit lagi di Nusantara, pemerintah menyadari bahwa modal yang diberikan kepada PT PELNI masih jauh dari mencukupi. Bank Ekspor Impor misalnya, menyediakan dana untuk pembelian kapal guna meningkatkan kekuatan armada KPM.

Pada Desember 1954, pemerintah Indonesia mengeluarkan Peraturan Pemerintah (PP) No. 61. Peraturan tersebut memberlakukan nasionalisasi bagi perusahaan-perusahaan pelayaran dalam pelabuhan (angkutan bandar) dan perusahaan bongkar-muat (veem) asing di pelabuhan seluruh Indonesia. Hal itu karena usaha dalam bidang Perusahaan Muatan Kapal Laut (PMKL) hanya boleh dimiliki oleh perusahaan nasional Indonesia, baik swasta maupun negeri. Peraturan ini juga berlaku bagi perusahaan Belanda seperti KPM dan SMN.

Persaingan antara KPM dan PELNI dalam pelayaran antarpulau dapat dilihat pada Tabel 1.
Dari Tabel 1 dapat diketahui bahwa meskipun jumlah kapal dari armada PT PELNI semakin meningkat, tetapi secara keseluruhan jumlah kapal KPM lebih banyak. Untuk pengangkutan barang, KPM juga jauh lebih unggul daripada PT PELNI (lihat Tabel 2).

Tabel 1. Perbandingan Jumlah Armada PELNI dan KPM tahun 1940-1958

\begin{tabular}{lll}
\hline Tahun & PELNI & KPM \\
\hline 1940 & - & 138 \\
1952 & 21 & 111 \\
1953 & 45 & 98 \\
1954 & 51 & 100 \\
1955 & 44 & 98 \\
1956 & 46 & 96 \\
1957 & 50 & - \\
1958 & 57 & - \\
\hline \multicolumn{3}{c}{ Sumber: (BPS, 1959: 174). }
\end{tabular}

Tabel 2. Perbandingan Muatan dan Jumlah Kapal KPM dan PELNI Tahun 1953-1957

\begin{tabular}{ccccccc}
\hline Thn & \multicolumn{2}{c}{$\begin{array}{c}\text { Penumpang } \\
\text { 1000 }\end{array}$} & \multicolumn{2}{c}{$\begin{array}{c}\text { Muatan 1000 } \\
\text { ton }\end{array}$} & \multicolumn{2}{c}{$\begin{array}{c}\text { Jumlah } \\
\text { Kapal }\end{array}$} \\
\cline { 2 - 7 } & KPM & PELNI & KPM & PELNI & KPM & PELNI \\
\hline 1953 & 789 & 13 & 3.630 & 438 & 98 & 45 \\
1954 & 701 & 35 & 3.312 & 720 & 100 & 51 \\
1955 & 756 & 40 & 3.176 & 968 & 98 & 44 \\
1956 & 744 & 48 & 2.999 & 1.006 & 96 & 46 \\
$1957^{*}$ & 558 & 93 & 2.820 & 1067 & - & 50 \\
\hline
\end{tabular}

Sumber: (BPS, 1959: 174; Dick, 1987: 23).

Berdasar pada Tabel 2 diketahui bahwa penumpang dan barang yang diangkut oleh kapal PT PELNI terus-menerus mengalami peningkatan. Namun demikian, secara keseluruhan KPM tetap menjadi pemain utama dalam pelayaran antarpulau. Bahkan, pada 1957 PT PELNI mengalami kerugian.

Bagi pemerintah Indonesia pembangunan dan pengembangan pelayaran nasional melalui pendirian PT PELNI tidak bisa dihentikan dan ditawar lagi. Guna memperkuat posisi perusahaan pelayaran dalam negeri, maka pada 18 Nopember 1957 diselenggarakan Musyawarah Nasional Pelayaran. Keingingan semacam itu pernah disampaikan secara terbuka oleh Presiden Soekarno pada 3 Mei 1956. Ketika itu, ia secara sepihak menandatangani undang- 
undang pembatalan kesepakatan Konferensi Meja Bundar.

Pembatalan itu berarti Indonesia tidak berkewajiban lagi untuk melindungi aset-aset dan tidak mengizinkan perusahaan-perusahaan asing khususnya Belanda beroperasi di Indonesia. Kedudukan ekonomi Belanda di Indonesia menjadi goyah. Di samping itu, pembayaran hutang pokok beserta bunganya yang harus ditanggung oleh pemerintah Indonesia sebagai hasil kesepakatan KMB juga ditangguhkan.

Selanjutnya sebagai pressing terhadap Belanda, maka pada 27 Desember 1958 dikeluarkan UU No. 86 tahun 1958. UU tersebut mengisyaratkan untuk melakukan nasionalisasi semua perusahaan Belanda di Indonesia dan sebagai perwujudan dari kedaulatan politik yang telah dicapai. Tujuan lain yang tidak kalah penting adalah mewujudkan ekonomi nasional.

Sementara itu, bagi KPM, pembentukan Komisi Pemerintah pada 1955 sebagai persiapan pengambilalihan secara resmi (nasionalisasi) KPM membuat hubungan antara Indonesia dan Belanda semakin memburuk. KPM harus memperhitungakan kemungkinan-kemungkinan buruk yang dapat menimpanya, misalnya gerakan buruh.

Pada 9 Desember 1957, KPM ditempatkan di bawah pengawasan Panitia Penguasa, yang terdiri atas para perwira tinggi militer, para pegawai KPM bangsa Indonesia, dan para pegawai dari kementerian yang bersangkutan. Keberadaan Panitia Penguasa menjelaskan posisi pemerintah RI untuk mengendalikan KPM, dalam arti KPM harus tunduk kepada pemerintah RI yang sedang membangun dan mengembangkan ekonomi nasional dalam bidang pelayaran melalui pendirian PT PELNI. Oleh karena itu, jalur pelayaran antarpulau harus dikuasai dan dikendalikan oleh PT PELNI.

Pada saat yang sama, Panitia Penguasa menahan sejumlah kapal KPM. Direksi KPM tidak tinggal diam dan melaporkan aksi sepihak itu kepada perusahaan asuransi Inggris yaitu Lloyd of London dimana KPM mengasuransikan kapal-kapalnya. Atas laporan itu Lloyd menge- luarkan pernyataan bahwa pihaknya akan memberikan jaminan ganti rugi kapal-kapal KPM yang hilang dalam kategori sebagai korban perang (molestpolis). Pernyatan ini menandai keterlibatan pihak ketiga dalam konflik KPM dengan pemerintah Indonesia. Lloyd yang didukung oleh pemerintah Inggris mengancam kepada Indonesia akan menuntut ganti rugi jauh lebih besar dari premi jaminan asuransi yang akan diberikan kepada KPM. Lloyd juga akan memboikot jaminan asuransi atas seluruh kapal yang dimiliki oleh Indonesia, jika kapal-kapal KPM yang ditahan tidak segera dibebaskan.

Pemerintah Indonesia akhirnya membebaskan semua kapal KPM. Namun demikian, dalam konferensi pers pada Jum'at 21 Maret 1958 Menteri Pelayaran Nasir menegaskan bahwa sejak hari itu sejarah KPM di Indonesia telah berakhir. Artinya, KPM harus disingkirkan dari aktivitas dalam jalur pelayaran antarpulau di Indonesia. Natsir juga menyatakan bahwa KPM dan Belanda tentu kecewa, karena mereka mengira akan memperoleh ganti rugi yang sangat besar atas kapal-kapalnya yang ditahan oleh Indonesia. Keputusan Indonesia untuk membebaskan kapal-kapal KPM dengan demikian sesungguhnya merupakan kekalahan bagi KPM.

KPM menganggap pembebasan itu sebagai Pyrruszege. Direksi KPM sebetulnya lebih berharap KPM dapat beroperasi kembali di Indonesia, atau menerima pembayaran klaim asuransi dalam jumlah yang fenomenal, sehingga dapat melanjutkan usahanya di luar Indonesia dengan membeli kapal-kapal baru. Oleh karena keduanya gagal, KPM menghadapi masalah karena seluruh armada kapalnya sebetulnya didesain untuk pelayaran antarpulau di Indonesia. Kapal-kapal itu akan sulit gunakan dalam jalur pelayaran di negara lain yang kondisi geografisnya berbeda.

Langkah pemerintah dalam menghadapi KPM sesungguhnya merupakan bagian dari rencana nasionalisasi seluruh perusahaan asing khususnya Belanda di Indonesia. Pemerintah telah mengeluarkan UU No. 86 tahun 1958 tentang nasionalisasi perusahaan Belanda. Posisi KPM di Indonesia tidak mungkin dipertahankan 
lagi, karena nasionalisasi merupakan program nasional. Secara teknis pelaksanaan nasionalisasi itu akan diatur dalam Peraturan Pemerintah No. 2 tahun 1959 tentang Pokok-pokok Pelaksanaan Nasionalisasi Perusahaan Belanda. Untuk melaksanakan nasionalisasi itu dibentuk Badan Nasionalisasi Perusahaan Belanda. Secara formal, nasionalisasi KPM baru terjadi ketika dikeluarkan Peraturan Pemerintah No. 34 tahun 1960 tentang ketentuan mengenai nasionalisasi perusahaan KPM di Indonesia.

Berdasar peraturan pemerintah itu maka kantor pusat, bagian, dan seluruh kantor cabang KPM terkena peraturan nasionalisasi. Namun demikian, sejumlah kapal KPM yang semula ditahan pihak Indonesia dan telah dibebaskan, tidak ikut dinasionalisasi karena telah pergi dari wilayah perairan Indonesia. Semua aset KPM yang telah dinasionalisasi diserahkan kepada PT PELNI sebagai aset atau modal tambahan.

\section{SIMPULAN}

Persaingan antara NV KPM dengan PELNI yang berlanjut dengan konflik antara KPM dengan pemerintah Indonesia, dapat dilihat dari posisi masing-masing perusahaan dan peranannya dalam aktivitas pelayaran di Indonesia. Melihat aktivitasnya, KPM tidak hanya penting secara komersial, tetapi juga penting dari sisi strategis dan simbolis. Sisi strategis KPM sangat penting dan sangat diperlukan dalam ikut menjaga stabilitas politik dan integrasi Hindia Belanda. Sementara dari sisi simbolis KPM merupakan simbol dominasi ekonomi Belanda di Indonesia.

Di sisi lain, PT PELNI seperti halnya KPM, juga harus berfungsi sebagai centraal vervoersapparaat. Oleh karena itu, pemerintah c.q. PT PELNI menganggap KPM yang mendominasi pelayaran antarpulau di Indonesia merupakan pesaing dan penghambat pembangunan nasional dalam bidang pelayaran. Untuk menggantikan posisi KPM, pemerintah RI berusaha melakukan perundingan untuk bekerja sama, tetapi tidak berhasil. Tampaknya KPM tetap mengandalkan jaminan yang diamanatkan oleh kesepakatan Konferensi Meja
Bundar, keunggulannya dalam bidang manajerial, sumber daya manusia, dan kekuatan armada. Hal ini membuat KPM memiliki kepercayaan diri yang sangat tinggi dan tetap bertahan di Indonesia sampai 1958. Akibatnya KPM harus diusir dari Indonesia sementara perusahaan-perusahaan asing yang lain meninggalkan Indonesia melalui nasionalisasi secara damai dan terhormat.

Nasionalisasi perusahaan-perusahaan Belanda merupakan pilihan tepat. Program ini terbukti mampu mematahkan dominasi ekonomi Belanda dengan satu pukulan dan sekaligus merampungkan dekolonisasi.

\section{CATATAN}

${ }^{1}$ Kerajaan-kerajaan maritim merupakan pusat kekuasaan raja-raja atau penguasa di kota-kota pelabuhan, atau merupakan bagian dari wilayah suatu kerajaan yang lebih besar. Kerajaan-kerajaan semacam itu tidak mengandalkan pendapatan negara dari pajak rakyat atau petani, tetapi dari keuntungan dalam aktivitas pelayaran dan perdagangan.

${ }^{2}$ Di kota Semarang misalnya, Gubernur Jawa Tengah waktu itu, yaitu Wongsonegoro, dengan senang hati menyambut kedatangan Sekutu yang akan melucuti tentara Jepang. Ia menyediakan akomodasi yang diperlukan oleh Jendral Bethell dan pasukannya selama bertugas di kota Semarang, dengan persyaratan sekutu harus mengakui kedaulatan RI. Waktu itu Presiden Soekarno juga menyempatkan diri datang ke Semarang untuk melakukan perundingan perdamaian dengan Sekutu (Departemen Pendidikan dan Kebudayaan, 1985: 72-77).

\section{REFERENSI}

à Campo. J.N.F.M. (1992). De Koninklijke Paketvaart Maatschappij: Stoomvaart and staatsvorming in de Indische archipel 18881914. Hilversum: Verloren.

Ali, S. (1966). "Interisland Shipping”, Bulletin of Indonesian Economic Studies 3.

Bebler, Ales. (1963). Pantulan Zaman Bahari Indonesia. Djakarta: Djambatan.

Chia Joshua, Yeong Jia, dan Loh Pei Ying (2007). "Rediffusion". Singapore Infopedia, diakses pada 9 November 2014, http://infopedia. nl.sg/articles/ SIP_1198_2008-10-24.html. 
Departemen Pendidikan dan Kebudayaan (1985). Sejarah Revolusi Kemerdekaan 1945-1949 Jawa Tengah. Semarang: tanpa penerbit.

Drake, C. (1989). National Integration in Indonesia: Patterns and Policies. Honolulu: University of Hawaii Press.

Ensiklopedi Nasional Indonesia, Jilid VII (1989). Jakarta: Cipta Adi Pusaka.

Heuken, Adolf (2001). Sumber-Sumber Sejarah Asli. Jakarta: Cipta Loka Caraka jilid II.

Houben, V. J. H.., H. M. J. Maier, and W. van der Molen (1992). Looking in Odd Mirrors: The Java Sea, Leiden: Vakgroep Talen en Culturen van Zuidoost-Asië en Oceanië Leiden Universiteit.

Kerkhof, J. P. van de (2005). "Onmisbaar maar Onbemind: De Koninklijke Paketvaat Maatschappij en Billiton Maatschappij in het Onafhankelijke Indonesie”, dalam Tijdschrift voor Sociale en Economische Geschiedenis 2, No. 5, hlm. 134.

Koninklijke Paketvaart Maatschappij (1938). KPM: Official Yearbook 1837-1938. Batavia: De Unie.

Meilink-Roelofsz, M. A. P. (1962). Asian Trade and European Influence: In the Indonesian Archipelago between 1500 and about 1630. The Hague: Martinus Nijhoff.

Mulyana, Slamet (1980). Dari Holotan ke Jayakarta. Jakarta: Yayasan Idayu.

Nasution, A. H. (1977). Sekitar Perang Kemerdekaan Indonesia, Jilid III. Bandung: Angkasa.

Panitia Penjusun Naskah Buku '20 Tahun Indonesia Merdeka' (1966). 20 Tahun Indonesia Merdeka, Jilid 7. Jakarta: Departemen Penerangan RI.

Ricklefs, M. C. (1974). Yogyakarta under Sultan Mangkubumi 1749-1792: A History of the Division Java. London: Oxford University Press.

Staatsblads No. 48, 4 September 1888.

Sulistiyono, Singgih Tri (2003). The Java Sea Network: Patterns in The Development of Interregional Shipping and Trade in The Process of National Economic Integration in
Indonesia, 1870 - 1970. Proefschrift ter van de Graad van Doktor aan de Universiteit Leiden.

Walcott, A. S. (1914). Java and Her Neighbors: A Traveler's Note in Java, Celebes, the Moluccas and Sumatra. New York and London: Knickerbocker Press.

Wertheim, W. F. (1969). Indonesian Society in Transition: A Study of Social Change. The Hague: W. van Hoeve.

"Koninklijke Paketvaart Maatschappij 18881967”, http: //www.theshipslist.com/ ships/lines/kpm.htm. 